Article

\title{
An Investigation into the Factors Contributing to Domestic Vi- olence in Koforidua in the New Juaben Municipality of Ghana
}

\author{
James Badu ${ }^{1}$, Eric Osei Yaw ${ }^{2}$, Abena Boakyewa ${ }^{2}$, Philip Owusu-Ansah ${ }^{3}$, Janet Dansoah Oppong ${ }^{4}$, Mariam Ap- \\ piah 5
}

How to cite this paper: Badu, J., Yaw, E. O., Boakyewa, A., OwusuAnsah, P., Oppong, J. D., \& Appiah, M. (2022). An Investigation into the Factors Contributing to Domestic Violence in Koforidua in the New Juaben Municipality of Ghana. Open Journal of Educational Research, 2(1), 1-8. Retrieved from https://www.scipublica-

tions.com/journal/index.php/ojer/article/view/185

Received: November 02, 2021 Accepted: February 15, 2022 Published: February 17, 2022

Copyright: (c) 2022 by the authors Submitted for possible open access publication under the terms and conditions of the Creative Commons Attribution (CC BY) license (http://creativecommons.org/licenses /by/4.0/).

\author{
${ }^{1}$ Department of Social Sciences, Seven Day Adventist College of Education, Koforidua-Asokore, Ghana \\ 2 Department of Social Sciences, St. Louis College of Education, Kumasi, Ghana \\ ${ }^{3}$ Department of Social Sciences, St. Monica's College of Education, Ashanti-Mampong, Ghana \\ ${ }^{4}$ Department of Technical and Vocational, Seven Day Adventist College of Education, Koforidua-Asokore, \\ Ghana \\ ${ }^{5}$ Department of Social Sciences, Gbewa College of Education, Pusigah, Ghana \\ *Correspondence: bordohlity@yahoo.co.uk
}

\begin{abstract}
The purpose of the study was to investigate the factors contributing to domestic violence in Koforidua in the New Juaben Municipality of Ghana. The population of the study consisted of 340 men selected from four communities in Koforidua. Purposive sampling technique 4 communities. Using the Krejcie and Morgan table, a sample size of 340 men were selected which is appropriate for a population of 3428 with an alpha level of 5 percent in a quantitative study. The selection was based on the fact that these communities registered the highest cases of domestic violence in the Municipality. The main instrument used for the study was structured questionnaire. Data analysed using SPSS (Statistical Product for Service Solution, version 20). Statistical tools such as frequency distribution tables, percentages, charts and cross tabulation was used. The frequency tables were used to give the summary of the data for easy understanding and comparison. The study revealed that men perceive that factors like show of power, exposure to domestic violence, poor communication in marriage, unemployment and poverty, control of women through discipline and women's low academic achievement are the triggers of domestic violence in a marital relationship. The study recommended that effort ought to be put in place to unravel the mystery surrounding male supremacy over women at both institutional and community levels by DOVVSU, Gender Advocacy Groups and other institutions to benefit humanity and society at large.
\end{abstract}

Keywords: Factors, Domestic, Violence, Koforidua, New Juaben Municipality

\section{Introduction}

Public efforts at addressing cases of abuse and domestic violence in Ghana came to the fore in 1997 following a nation-wide study on the prevalence, patterns and responses to gender violence undertaken by a partnership of NGOs under the leadership of the Gender Studies and Human Rights Documentation Centre [1,2]. This in effect contributed to the establishment of the Women and Juvenile Unit (WAJU, now Domestic Violence and Victims Support Unit, DOVVSU) by the Police Administration in 1998 initially in Accra and Kumasi to respond to the increasing reports of abuse and violence against women and children [2]. By 2002, WAJU offices had been extended to all regions, but reported increases in violence, the sheer volume of cases, the attitudes of police personnel, inadequacies in the Criminal Code and family and societal pressures on complainants led to the push for more comprehensive legislation to deal with cases of domestic violence [1,3]. 
The draft Domestic Violence legislation prepared by the office of the Attorney General in 2002, meant to offer a holistic and effective legal framework for addressing domestic violence in Ghana; provide broad redress for cases of domestic violence, sanctions on perpetrators and protective remedies for victims; and to improve Ghana's compliance with its legal obligations under international human rights standards [2]. The Act among other things contains provisions criminalizing various acts of violence; physical, sexual (within or outside of marriage) and between a wide variety of individuals in a domestic relationship including family and non-family members such as house-helps and people who do not physically live together, economic and psychological abuse, intimidation and harassment [2]. The Act makes provision for protection orders, psychological and rehabilitative services for victims or perpetrators, and processes for promotion of reconciliation $[4]$.

The passage of the Act in 2007 has been lauded as an important first step towards addressing gender-based violence in Ghana (United Nations, 2008). In addition to that, efforts made by government and Non-Governmental Organizations, gender advocacy groups like Federation of International Women Lawyers (FIDA), the Gender Violence Survivors Support Network (GVSSN), Action Aid Ghana, Ark Foundation, Network for Women's Right in Ghana (NETRIGHT) among others through intervention measures such as, following up on reports of domestic violence, providing education on domestic violence, providing some support base for victims of domestic violence and counselling sessions to curb the menace. All these efforts serve to prevent the incidence of domestic violence in Ghana in several ways [2,5]. However, efforts to eliminate domestic violence like have been restrained by norms, attitudes and perceptions of societies and individuals, men and women alike, towards its eradication [1,3].

Male violence against women has been placed on the national political agenda as a priority in most countries in Africa, as statistics are overwhelmingly high [6]. A troubling aspect of male violence is its benign social and cultural acceptance in several countries [7]. In of view that, this acceptance has led to violence being viewed as a normal male behaviour that is taken for granted and not problematized [7]. Literature also shows that male perpetrators tend to deny and minimize their assaultive and abusive actions [8]. Blacklock further posits that, men minimize violence by denying the abuse because the particular acts are not included in their definition of violence and abuse, most frequently, this will mean omitting actions such as pushing, holding, blocking and throwing things [8]. Perpetrators for example perceive sexual abuse as a different form of domestic violence and that they do not accept non-physical abusive behaviour as violence [7]. Feminists believe that such discourses are evidence of how men have been accustomed to patriarchal values to the extent of failing to appreciate actions such as sexual, verbal and emotional abuse as violence [9].

Violence against women as a continuum which includes diverse acts such as: sexual harassment, violent rape, hitting with sticks and other objects, assaulting with fists, stabbing with a knife and murder [10]. Research has confirmed the link between male violence and the rise in HIV and AIDS statistics among women. This is due to the fact that; male violence robs women of power to have a say over their sexuality [11]. The study seeks to examine what men perceive as a contributing factors to domestic violence in Koforidua in the Eastern Region of Ghana. The study was guided by a research question - What do men perceive as the major contributing factors to domestic violence?

\section{Materials and methods}

Therefore, descriptive design was adopted for the study to enable the researcher obtain information concerning the current status of the phenomena (domestic violence) to describe "what exists" with respect to variables or conditions in the situation. The population of the study consisted of 340 men selected from four communities in Koforidua. Purposive sampling technique 4 communities. Using the Krejcie and Morgan table, a sample 
size of 340 men were selected which is appropriate for a population of 3428 with an alpha level of 5 percent in a quantitative study. The selection was based on the fact that these communities registered the highest cases of domestic violence in the Municipality as shown in the Table 1 below.

Table 1. Distribution of communities selected and the sample size.

\begin{tabular}{ccc}
\hline Name of community & Estimated Population & Sample size \\
\hline Agavenya & 705 & 73 \\
Korle Nkwanta & 996 & 105 \\
Asikasu & 856 & 90 \\
Kofikrom & 695 & 72 \\
\hline Total & $\mathbf{3 2 6 5}$ & 340 \\
\hline
\end{tabular}

Data was collected from both primary and secondary sources. The primary data was collected from the field through the use of structured questionnaire. The secondary sources included documents from peer review articles and journals, published thesis, reports from Domestic Violence and Victim Support Unit (DOVVSU). The main instrument used for the study was structured questionnaire. Data analysed using SPSS (Statistical Product for Service Solution, version 20). Statistical tools such as frequency distribution tables, percentages, charts and cross tabulation was used. The frequency tables were used to give the summary of the data for easy understanding and comparison.

\section{Results and Discussions on Factors Contributing to Domestic Violence}

The section presented results and discussions on factors men perceive as contributing to domestic violence. The results related to the research question - What do men perceive as the major contributing factors to domestic violence? presented in Table 2.

Table 2. Factors contributing to domestic violence

\begin{tabular}{|c|c|c|c|c|}
\hline Factors & $\begin{array}{c}\text { Strongly Disa- } \\
\text { gree }(\%)\end{array}$ & Disagree (\%) & $\begin{array}{l}\text { Strongly } \\
\text { Agree(\%) }\end{array}$ & Agree $(\%)$ \\
\hline Show of power by men & 14.1 & 11.2 & 26.5 & 48.2 \\
\hline Abuse of alcohol and drugs & 35.0 & 49.7 & 9.1 & 6.2 \\
\hline Exposure to DV in the family & 14.7 & 10.9 & 43.2 & 31.2 \\
\hline Poverty and stress in marriage & 5.6 & 9.4 & 38.5 & 46.5 \\
\hline Poor communication in marriage & 88 & 9.1 & 45.6 & 36.5 \\
\hline Control of women through discipline & 44 & 8.8 & 49.7 & 37.1 \\
\hline Women's low academic achievement & 13.5 & 12.1 & 41.2 & 33.2 \\
\hline
\end{tabular}

\section{Source: Field data (2014)}

Out of 340 respondents, $74.7 \%$ agree that men show their power and control women in marriage or relationship, while $25.3 \%$ disagree. This is in line with Carrington \& Phillips (2006) who posits that power and authority by men is the main factor contributing to domestic violence against women. They further confirm that male privilege works at both individual level and at a social level and reinforces male authority and control over women. The violence of men against women has its roots in inequalities between the genders. Patriarchal traditions also encourage men to believe that controlling their partner through power and aggression is a justified behaviour. In relation to this, Weber's con- 
ceptualization of power in society confirms the acceptance of men's super-ordinate powers in marriage and in society by women in Ghana [13]. For Weber, the social benefit of power will result from the institutionalization and legitimation of the power that some actors hold over others; in a manner that majority of the members within the larger social system are motivated to act in ways that contribute to order and stability rather than disruption and instability.

From Table 2, the result in the use of alcohol and drugs as a cause of domestic violence shows that $84.7 \%$ disagree while $15.3 \%$ agree. The result is in line with Mitchell (2003) who postulates that alcohol and drugs do not necessarily cause abuse as it is believed, but it serves as an excuse for men to blame alcohol or drug use as causing abusive reactions. In a related study, the connection between alcohol consumption and drug use and domestic violence remains somewhat contentious, there is a notable shift and growing recognition that alcohol is not a direct cause of domestic violence [14, 15].

In fact, what is worthy of note is that this result was opposed by the notion that virtually every study of aggression in families shows that alcohol consumption is a strong correlate of violence [15] a similar study also see alcohol and drug use believed to be contributing to domestic violence [16]. Table 2, again, shows the result of the respondents on unemployment and poverty. Majority of the respondents (85\%) were of the opinion that poverty and unemployment in marriage relationships can erupt into violence, however $15 \%$ disagree. The finding is confirmed by a previous study that violent practices are deployed by men against women in attempt to maintain a particular self-image and selfevaluation in the face of real or imagined threats to prove that they are "real" men and their women are under their control when confronted with financial constraints [17]. This is similar to the notion that economic and social factors such as low wages, unemployment, lack of economic resources and inadequate housing augment women's vulnerability and contribute to domestic violence [18]. Again, the study is confirmed by the argument made by authors that patriarchy system which feminists believe to be a major cause of domestic violence is one variable in a complex constellation of causes which among others are poverty, unemployment, socio-economic status, and cohabiting status. A woman's employment status has critical symbolic importance as it signifies a challenge to the culturally prescribed norm of male dominance and female dependence. He continued to say that where a man lacks this sign of dominance, violence may be the ultimate means of reinstating his authority over his wife [19].

From Table 2, $82.1 \%$ of the respondents agree that poor communication in marriage or relationship can lead to domestic violence, however, $17.9 \%$ disagree. This is in line with Ridley and Feldman who posits that there is a strong correlation between males who are poor communicators toward their partners and the frequency and severity of domestic violence. Verbal aggression and communication differences between males and females result in ineffective problem-solving or failure to agree can lead to domestic violence. They continue to point out that emotional distance and difference in problem resolution abilities can lead to discord. They observed that if after conflict resolution, there is an absence of discussion; it may lead to more argument [21]. A related study, posit see that good communication is free of abusing or trying to control the other. They continued that the need for control over another person in a relationship leads to domestic violence and this occurs due to change in communication style between individuals and results in the possibility of violence when mutual agreement or benefit is not reached by both partners [22].

Majority of the respondents $(74.4 \%)$ were of the opinion that men's history and exposure to family violence are likely to cause domestic violence towards one's partner. However, $25.6 \%$ of the respondents disagreed. These findings are in line with Arriaga and Foshee who found out that when individuals have experience with violent parents who were violent toward one another, there is an increased likelihood of perpetrating violence to their partners in the future [23]. They continue to say that the concept of witnessing 
parental abuse and causing intimate partner violence later is a trend found throughout violence literature. The findings of the study was also confirmed by a similar study postulating that not only witnessing parental violence as a child is important to later perpetrating violence, but also those adolescents more frequently exposed are likely to assault their partners [24]. The survey observed that men who had witnessed wife assault in their families of origin had rates of battering three times greater than those who did not. It also states that males and females who were subjected to physical punishment as children also had higher rates of marital violence as adults. Again, the finding is in line with a study conducted in United Kingdom that established that violence in one's family of origin was associated to acceptance of interpersonal violence [25]. also holds the same view which is also supported by the current finding. They hold the view that if the family of origin handles stress and frustrations with anger and aggression, the child who has grown up in such an environment is at greater risk of exhibiting those same behaviours, witnessed and experienced as an adult [26]. Furthermore, the finding is not different from a research conducted by Chandler and Kruger who found out that males who were exposed to violence in their families of origin are more likely to become perpetrators of domestic violence than males who were not exposed to domestic violence during childhood [27]. This clearly depicts that respondents really accepted there is a correlation between exposure to physical violence and domestic violence.

The findings on perception of wife's low academic achievement as a contributing factor to domestic violence is clearly shown in Table 2 . It reveals that $74.4 \%$ agreed to the idea however, $25.6 \%$ disagreed. The finding of this study is in support of the argument hat those women who are mostly uneducated and uncertain of their rights and available resources are vulnerable and prone to domestic violence. Therefore, lack of knowledge, low academic achievements and illiteracy are factors accounting for domestic violence. He further argues that women who are illiterates lack the necessary skills to obtain a job and are often more vulnerable to domestic violence due to lack of freedom [28]. In furtherance to this, a study also confirmed that educational disparities are a more powerful predictor of violence than power, and that men who have a higher level of education perpetrated more severe violence on their partners [29]. Indeed, low academic achievements can contribute to domestic violence. From the study, it revealed that there is a kind of correlation between low academic achievement and domestic violence.

\subsection{Correlational Analysis (Perception and Level of Education)}

Table 3 displays the correlational analysis between educational level of respondents and their perception about the concept of domestic violence.

The results indicate that there is a strong positive correlation which is highly significant between men's perception about the concept of domestic violence and their educational level. All the values displayed that correlations were significant at 0.01 significant levels which means that the significant values (p-values) were less than 0.01 (Table 3 ). This finding is in line with other studies that domestic violence is a worldwide problem perpetrated by men regardless of their educational status. They continued to explain that due to how most African communities are structured along patriarchal lines, men see themselves as overloads over women regardless of their educational background which goes a long way to shape their perception leading to perpetuation of violence in the society [ 30 , 31].

The finding from the correlational analysis in Table 4. indicate that there were highly significant and strong positive correlation between men's perception of the concept of domestic violence and their age. The relationships are said to be strong because the correlation coefficient ranged from 0.912 to as high as 0.931 . These were significant at 0.01 significant level as all the $\mathrm{p}$-values are less than $0.01(\mathrm{p}<0.01)$. This implies that, even older men believe assaulting women and using violence as a panacea for addressing marital problems. This could be well in line with the social learning theory, which posits that because 
a great number of people who batter partners is due to exposure in their childhood to similar scenarios without any reprimand; they in turn transfer these tendencies as a panacea to solve marital problems hence the trend of violence in marriages regardless of the age of people [32].

Table 3. Correlation between perception of DV and Level of Education

\begin{tabular}{|c|c|c|}
\hline \multicolumn{2}{|l|}{ Variable } & Educational level \\
\hline \multirow{3}{*}{ Assault a relationship or marriage is part and parcel of marriage. } & Pearson Correlation & $0.730^{* *}$ \\
\hline & Sig. (2-tailed) & 0.000 \\
\hline & $\mathrm{N}$ & 340 \\
\hline \multirow{3}{*}{ Sexual abuse in marriage/relationship not seen as violence. } & Pearson Correlation & $0.807^{* *}$ \\
\hline & Sig. (2-tailed) & .000 \\
\hline & $\mathrm{N}$ & 340 \\
\hline \multirow{3}{*}{ Payment of bride price guarantees men to control women. } & Pearson Correlation & $0.797^{* *}$ \\
\hline & Sig. (2-tailed) & .000 \\
\hline & $\mathrm{N}$ & 340 \\
\hline \multirow{3}{*}{ Sanctioning women for being insolent in marriage/relationship. } & Pearson Correlation & $0.812^{* *}$ \\
\hline & Sig. (2-tailed) & .000 \\
\hline & $\mathrm{N}$ & 340 \\
\hline \multirow{3}{*}{$\begin{array}{c}\text { Sanctioning women for not keeping relationship/marital issues } \\
\text { secret within bounds. }\end{array}$} & Pearson Correlation & $0.807^{* *}$ \\
\hline & Sig. (2-tailed) & .000 \\
\hline & $\mathrm{N}$ & 340 \\
\hline \multirow{3}{*}{ Violence as a means to solve marital/relationship problems. } & Pearson Correlation & $0.778^{* *}$ \\
\hline & Sig. (2-tailed) & .000 \\
\hline & $\mathrm{N}$ & 340 \\
\hline
\end{tabular}

\section{Source: Field data (2014)}

\subsection{Correlational analysis (Perception of DV and Age of respondents)}

Table 4. Correlations between perception of DV and Age

\begin{tabular}{|c|c|c|}
\hline \multicolumn{2}{|l|}{ Variables } & Age of Respondents \\
\hline \multirow{3}{*}{$\begin{array}{c}\text { Assault in a relationship or marriage as part and parcel of mar- } \\
\text { riage. }\end{array}$} & Pearson Correlation & $0.921^{* *}$ \\
\hline & Sig. (2-tailed) & 0.000 \\
\hline & $\mathrm{N}$ & 340 \\
\hline \multirow{3}{*}{ Sexual abuse in marriage/relationship not seen as violence. } & Pearson Correlation & $0.903^{* *}$ \\
\hline & Sig. (2-tailed) & .000 \\
\hline & $\mathrm{N}$ & 340 \\
\hline \multirow{3}{*}{$\begin{array}{l}\text { Payment of bride price guarantees men the authority to control the } \\
\text { woman. }\end{array}$} & Pearson Correlation & $0.917^{* *}$ \\
\hline & Sig. (2-tailed) & .000 \\
\hline & $\mathrm{N}$ & 340 \\
\hline \multirow{3}{*}{ Sanctioning women for being insolent in marriage/relationship. } & Pearson Correlation & $0.930^{* *}$ \\
\hline & Sig. (2-tailed) & .000 \\
\hline & $\mathrm{N}$ & 340 \\
\hline \multirow{3}{*}{$\begin{array}{l}\text { Sanctioning women for not keeping relationship/marital issues se- } \\
\text { cret within bounds. }\end{array}$} & Pearson Correlation & $0.931^{* *}$ \\
\hline & Sig. (2-tailed) & .000 \\
\hline & $\mathrm{N}$ & 340 \\
\hline \multirow{3}{*}{ Violence as a means to solve marital/relationship problems } & Pearson Correlation & $0.912^{* *}$ \\
\hline & Sig. (2-tailed) & .000 \\
\hline & $\mathrm{N}$ & 340 \\
\hline
\end{tabular}




\section{Source; Field data (2014)}

\section{Conclusions}

The study revealed that men perceive that factors like show of power, exposure to domestic violence, poor communication in marriage, unemployment and poverty, control of women through discipline and women's low academic achievement are the triggers of domestic violence in a marital relationship.

\section{Recommendations}

The phenomenon of male perception towards domestic violence can be conceptualized as occurring at multiple levels of analysis: individual, relational, community and collective. At the individual level, men have come to internalize dominant cultural and social notions of masculinity and a sense of personal worthlessness if their actions appear to subvert the social order. In relationship with their community, men are regarded as powerful and heads of households, and are treated as such by society. These dominant notions of male supremacy and subordination of women reflect institutional expression of power inequality and are embedded in structural arrangements that are manifested in social policies and community settings. In this regard much effort ought to be put in place to unravel the mystery surrounding male supremacy over women at both institutional and community levels by DOVVSU, Gender Advocacy Groups and other institutions to benefit humanity and society at large.

Author Contributions: Conceptualization A. B; methodology, J. B, J. D. O and M. A; validation, J. B, E. O. Y., A. B. P. O. A., J. D.O and M. A; formal analysis, J. B., and A. B; investigation, J. B, E. O. Y., A. B. P. O. A., J. D. O and M. A; resources, J. B., J. D. O, and P. O. A.; data curation, J. B, E. O. Y., A. B. P. O. A., and M. A; writing-original draft preparation, J. B., E. O. Y., and P. O. A; writing-review and editing, E.O. Y. and J. D. O; visualization, J. B, E. O. Y., A. B. P. O. A., J. D. O and M. A supervision, J.B and E.R. O; project administration, J. B, E. O. Y., A. B. P. O. A., J. D. O and M. A.; All authors have read and agreed to the published version of the manuscript.

Funding: "This research received no external funding"

Data Availability Statement: Data is available on request from the corresponding author.

Acknowledgments: we acknowledge the Dr. Anthony Bordoh for his input and suggestions

Conflicts of Interest: "The authors declare no conflict of interest." "No funders had any role in the design of the study; in the collection, analyses, or interpretation of data; in the writing of the manuscript, or in the decision to publish the results".

\section{References}

[1] Coker-Appiah, D., \& Cusack, K. (eds). (1999). Breaking the silence and challenging the myths of violence against women and children in Ghana: report on a national study of violence. Accra, Gender Studies \& Human Rights Documentation Centre.

[2] Manuh, T. (2007). African Women and Domestic Violence. Assessed from www.opendemocracy.net/article/african women and domestic violence

[3] Prah, M. (1999) 'Outcomes of Women's and Children's Responses' Violence Against Women and children in Ghana. Accra: Gender Studies and Human Rights Documentation Centre.

[4] Act732. Domestic violence Act, Ghana.pdf. Parliament of the Republic of Ghana 2007:1-20.

[5] Institute of Development Studies (IDS), Ghana Statistical Services (GSS) and Associates (2016), Domestic Violence in Ghana: Incidence, Attitudes, Determinants and Consequences, Brighton: IDS.

[6] Jacobson-Widding, A. (1983). Identity: Personal and sociocultural. Stockholm: Almquist \& Wiksell.

[7] Plant S. (2006). Deconstructing Masculinity. Compiled by Redfern, C. Population Council (2008) Sexual and gender-based violence in Africa. Nairo: Publication Council Inc.

[8] Blacklock, N. (2001). Advances in Psychiatric Treatment. Domestic Violence: working with perpetrators, the community and its institutions. United Kingdom. 
[9] Loseke, D. R., Gelles, R. J., \& Cavanaugh, M. M. eds., 2005. Current Controversies on Family Violence. 2nd ed, Thousand Oaks, CA: SAGE Publications, Inc.

[10] Linda Mshweshwe, L. (2010). Understanding domestic violence: masculinity, culture, traditions. Heliyon, 6 (10), 1-5.

[11] Takyi, K. B., \& Lamptey, E. (2016). Faith and Marital Violence in Sub-Saharan Africa: Exploring the Links Between Religious Affiliation and Intimate Partner Violence Among Women in Ghana. PubMed 35 (1-2) 25-52

[12] Domestic Violence Act 2007, (Act 732). Domestic Violence and Victim Support Unit (DOVVSU) Report, 2010.Retrieved on March 26, 2021. Website: www.modernghana.com/.../dovvsu-to-ensure-peace-in-marriages-not- d.html.

[13] Boss, G. P., Doherty, W. J., LaRossa, R., Schumm, W. R., \& Steinmetz, S. K. (1993). Source Book of Family Theories and Methods: A contextual Approach. New York: Plenum press.

[14] González, L., \& Núria, R. P. (2020). "Gender norms and intimate partner violence," Journal of Economic Behavior E Organization, Elsevier, 178(C), 223-248.

[15] Gelles, R. J., \& Cornell, C. P. (1990). Intimate Violence in Families, 2nd ed. Sage, Newbury Park, Calif.,

[16] Kaufman G.B. (2001). Intervention with Abuse of Alcohol, Drugs \& Women. Men stopping violence Inc. menstoppingviolence.org

[17] Wood, K., Jewkes, R. 2001. “'Dangerous' Love: Reflections on Violence among Xhosa Township Youth." In Changing Men in South Africa, edited by Morrell, R., 317-36. Pietermaritzburg, South Africa: University of Natal Press.

[18] Diale, M. B. (2014). Black Adolescents Experiences of Domestic Violence in South Africa: A Solution Focused Group Therapy Intervention Approach. Mediterranean Journal of Social Sciences, 5 (16), 506 -516.

[19] Anderson, K.L. (1997). Gender, Status \& Domestic Violence: an integration of Feminist and Family Violence Approaches, National Council on Family Relations. Journal of Marriage and the Family. 59 (3): 655-699.

[20] Gelles, J., \& Cavanaugh, M (2005) 'Association is not causation: Alcohol and other drugs do not cause violence' in Loseke, D, Gelles, R., Cavanaugh, M (Eds.), Current Controversies on Family Violence. Thousand Oaks, CA: Sage.

[21] Ridley, C., \& Feldman, C. (2000) The role of conflict-based communication response and outcomes in male domestic violence toward female partners. Journal of Social and Personal Relationships, 17 (4-5) 552-573.

[22] Fall, K. Howard and Ford, J. (2004) Alternatives to Domestic Violence; A Homework Manual for Battering Intervention Groups.USA; Routledge.

[23] Arriaga, X., \& Foshee, V. (2004). Adolescent dating violence: Do adolescents follow in their friends' or their parents' footsteps? Journal of Interpersonal Violence, 19 (2), 162-184.

[24] Lackey, C. (2003). Violent family heritage, the transition to adulthood, and later partner violence. Journal of Family Issues, 24(1), 74-98.

[25] Peltzer, K., \& Pengpid, S. (2013). The severity of violence against women by intimate partners and associations with perpetrator alcohol and drug use in the Vhembe district, South Africa. African Safety Promotion Journal, 11 (1), 13-23.

[26] Mihalic, S.W., \& Elliott, D. (1997). If violence is domestic, does it really count? Journal of Family Violence, 12 (3), $293-311$.

[27] Chandler, M., \& Kruger, J. D (2005). Volunteers at risk! Experiences of lay counsellors at a support centre for abused women. New Voices in Psychology, 1, 70-80

[28] Tshesane, M., (2001), Women Abuse in the Family Context: An Ethological Approach, Department of Criminology. University of South Africa.

[29] Claes, J. A., \& Rosenthal, D. M. (1990). Men Who Batter Women: A Study in Power. Journal of Family Violence, 5,215-224. https://doi.org/10.1007/BF00980817

[30] Dienye, P. O., \& Gbeneol, P. K. (2009). Domestic violence against men in primary care in Nigeria. American Journal of Men's Health, 3(4) 333-339.

[31] Ampofo, A. A. (1993). Controlling and punishing women: Violence against Ghanaian women. Review of African Political Economy, $56,102-111$.

[32] Gosselin D. K., (2010) Intergenerational Transmission Theory Heavy Hands: An Introduction to the Crimes of Family Violence, Fourth Edition (pp. 75-77). Upper Saddle River, NJ: Pearson/Prentice Hall. 